\title{
Uji daya hambat ekstrak rimpang kunyit (Curcuma longa) terhadap pertumbuhan bakteri Staphylococcus aureus dan Pseudomonas sp.
}

\author{
${ }^{1}$ Andrew Pangemanan \\ ${ }^{2}$ Fatimawali \\ ${ }^{2}$ Fona Budiarso
}

\author{
${ }^{1}$ Kandidat Skripsi Fakultas Kedokteran Universitas Sam Ratulangi Manado \\ ${ }^{2}$ Bagian Kimia Fakultas Kedokteran Universitas Sam Ratulangi Manado \\ Email: andrew.christian33@yahoo.com
}

\begin{abstract}
Turmeric (Curcuma longa) is a plant that is known to have medicinal properties, especially the rhizome. The active compound that contained in the rhizomes are able to work as an antibacterial. This study aimed to measure the inhibitory of turmeric rhizome (Curcuma longa) extract against the growth of Staphylococcus aureus and Pseudomonas sp. This was an experimental laboratory study. The polar extract of turmeric rhizome (Curcuma longa) was tested by well method with concentration of $40 \%, 20 \%, 10 \%$, and $5 \%$. The result showed that the polar extract of turmeric rhizome (Curcuma longa) with a concentration of $40 \%, 20 \%$, $10 \%, 5 \%$ can inhibit the growth of Staphylococcus aureus with the average of each is 15,0 $\mathrm{mm}, 14,5 \mathrm{~mm}, 13,5 \mathrm{~mm}$ and $11,0 \mathrm{~mm}$ while Pseudomonas $s p$ with a mean diameter of each is 13,1 mm, 11,1 mm, 9,3 mm and 8,8 mm. Conclusion: The polar extract of turmeric rhizome (Curcuma longa) has an inhibitory effect against the growth of Staphylococcus aureus and Pseudomonas sp.
\end{abstract}

Keywords: curcuma longa, inhibition, staphylococcus aureus, pseudomonas sp

\begin{abstract}
Abstrak: Kunyit (Curcuma longa) merupakan salah satu tanaman yang dikenal berkhasiat sebagai obat terutama bagian rimpangnya. Senyawa aktif yang terkandung dalam rimpang mampu bekerja sebagai antibakteri. Penelitian ini bertujuan untuk mengukur daya hambat ekstrak rimpang kunyit (Curcuma longa) terhadap pertumbuhan bakteri Staphyococcus aureus dan Pseudomonas sp. Jenis peneitian yang digunakan adalah eksperimental laboratorik. Kadar ekstrak polar rimpang kunyit (Curcuma longa) yang diujikan dengan metode sumuran yaitu 40\%, 20\%, 10\% dan 5\%. Hasil penelitian menunjukkan bahwa ekstrak polar rimpang kunyit (Curcuma longa) dengan konsentrasi 40\%, 20\%, 10\%, 5\% dapat menghambat pertumbuhan Staphylococcus aureus dengan rerata masing-masing 15,0 mm, 14,5 mm, 13,5 mm, dan 11,0 mm sedangkan Pseudomonas sp dengan masing-masing rerata yaitu 13,1 mm, 11,1 mm, 9,3 $\mathrm{mm}$, dan $8,8 \mathrm{~mm}$. Simpulan: Ekstrak polar rimpang kunyit (Curcuma longa) mempunyai daya hambat terhadap pertumbuhan bakteri Staphylococcus aureus dan Pseudomonas sp.
\end{abstract}

Kata kunci: curcuma longa, daya hambat, staphylococcus aureus, pseudomonas sp

Obat-obatan tradisional yang berasal dari tanaman sudah digunakan oleh penduduk di belahan dunia sebagai obat alternatif untuk penyakit-penyakit tertentu. WHO (World Health Organization) menyebutkan 80\% penduduk dunia pernah menggunakan obat herbal. ${ }^{1}$ Daya tarik obat tradisional terutama berasal dari sifatnya yang alamiah sehingga dinilai lebih aman dan ditoleransi lebih baik dibandingkan obat modern. ${ }^{2}$ Para ahli dari berbagai Negara tidak hentihentinya mengadakan penelitian dan pengujian berbagai tumbuhan yang secara tradisional dipakai untuk penyembuhan penyakit tertentu. ${ }^{3}$ Beberapa penelitian dengan teknik modern telah dikonfirmasi 
bahwa beberapa tanaman dapat digunakan sebagai anti-inflamasi, antimikroba, antikanker, dan lain-lain. ${ }^{4}$

Indonesia mempunyai banyak tanaman yang berkhasiat obat. Salah satu tanaman obat yang sering digunakan oleh masyarakat adalah kunyit (Curcuma longa) terutama bagian rimpangnya. Manfaat rimpang kunyit sebagai obat tradisional antara lain untuk obat gatal, kesemutan, gusi bengkak, luka, sesak napas, sakit perut, bisul, kudis, encok, antidiare, penawar racun, dan sebagainya. ${ }^{5}$

Beberapa penelitian sebelumnya, telah diteliti aktivitas senyawa aktif dalam rimpang kunyit mampu menghambat pertumbuhan jamur, virus, dan bakteri baik gram positif dan negatif seperti Escherichia coli, Klebsiela pneumonia, ${ }^{6}$ Listeria monocytogenes, dan Salmonella. ${ }^{7}$

Tujuan penelitian ini ialah untuk mengukur daya hambat ekstrak rimpang kunyit (Curcuma longa) terhadap pertumbuhan bakteri Staphylococcus aureus dan Pseudomonas sp yang dikultur pada media agar.

\section{METODE PENELITIAN}

Penelitian ini menggunakan metode eksperimental laboratorik. Penelitian dilakukan di Laboratorium Mikrobiologi Farmasi, Fakultas MIPA Universitas Sam Ratulangi dari bulan Oktober sampai Desember 2015. Populasi dalam penelitian ini adalah semua rimpang kunyit (Curcuma longa). Sampel yang diambil adalah rimpang kunyit (Curcuma longa) yang di tanam di perkebunan Kelurahan Rurukan Kota Tomohon.

Prinsip penelitian adalah dengan pemberian bakteri Staphylococcus aureus dan Pseudomonas sp pada ekstrak polar rimpang kunyit (Curcuma longa) dalam media agar diharapkan dapat terlihat seberapa besar zona hambat yang akan dihasilkan oleh masing-masing dosis ekstrak terhadap pertumbuhan bakteri kemudian dibandingkan dengan kontrol positif ciprofloxacin dan kontrol negatif aquades.

\section{Pembuatan Ekstrak}

Rimpang kunyit dikeringkan selama 7 hari pada suhu kamar kemudian dihaluskan dan ditimbang sebanyak 250 gram, selanjutnya direndam dalam $1250 \mathrm{ml}$ etanol 95\% dan dibiarkan selama 2 hari sambil diaduk 5-15 menit setiap hari. Larutan kemudian disaring untuk memisahkan filtrat dan debris. Debris yang dihasilkan di rendam lagi dengan etanol kemudian disaring kembali. Filtrat hasil penyaringan I dan II dicampurkan dan dievaporasi menggunakan evaporator vakum, selanjutnya dikeringkan dalam oven selama 3 hari. Hasil dari evaporasi kemudian dibagi menjadi 4 konsentrasi yaitu $40 \%$, 20\%, 10\%, dan 5\%.

\section{Pembuatan Kultur dan Uji Antibakteri}

Biakan bakteri Staphylococcus aureus dan Pseudomonas sp disuspensikan dengan $\mathrm{NaCl}$ kemudian diatur kekeruhannya sama dengan larutan McFarland. Larutan kontrol positif dibuat dari tablet ciprofloxacin yang dihaluskan dalam mortar sedangkan kontrol negatif menggunakan aquades steril.

Media dasar nutrient agar dituangkan ke dalam 3 cawan petri sebanyak $15 \mathrm{ml}$ dan dibiarkan memadat, kemudian diletakkan 6 pencadang. Selanjutnya media nutrient agar yang mengandung suspensi bakteri uji dituang ke dalam 3 cawan petri dan dibiarkan memadat. Pencadang dikeluarkan sehingga terbentuk sumur untuk larutan uji.

Larutan uji ekstrak rimpang kunyit (Curcuma longa) dengan berbagai konsentrasi (40\%, 20\%, 10\%, 5\%), kontrol positif dan kontrol negatif diteteskan sebanyak $50 \mu \mathrm{l}$ pada sumur yang berbeda, kemudian cawan petri dimasukkan dalam inkubator pada suhu $37^{\circ} \mathrm{C}$ selama 24 jam. Diamati dan diukur diameter zona hambat yang tebentuk dengan menggunakan mistar.

\section{HASIL PENELITIAN}

Hasil pengujian daya hambat ekstrak polar rimpang kunyit (Curcuma longa) terhadap aktivitas pertumbuhan bakteri Staphylococcus aureus memiliki nilai positif. Rata-rata diameter zona hambat 
pada ekstrak 5\%, 10\%, 20\% dan $40 \%$ secara berurutan yaitu $11,0 \mathrm{~mm}, 13,5 \mathrm{~mm}$, $14,5 \mathrm{~mm}$, dan 15,0 mm. Hasil yang lebih jelas dapat dilihat pada Tabel 1.

Tabel 1. Diameter zona hambat ekstrak rimpang kunyit terhadap bakteri Staphylococcus aureus

\begin{tabular}{ccccc}
\hline Bahan Uji & $\begin{array}{c}\text { Petri } \\
\text { I } \\
(\mathrm{mm})\end{array}$ & $\begin{array}{c}\text { Petri } \\
\text { II } \\
(\mathrm{mm})\end{array}$ & $\begin{array}{c}\text { Petri } \\
\text { III } \\
(\mathrm{mm})\end{array}$ & $\begin{array}{c}\text { Rata- } \\
\text { rata } \\
(\mathrm{mm})\end{array}$ \\
\hline Aquades & 0,0 & 0,0 & 0,0 & 0,0 \\
Ekstrak 5\% & 14,0 & 8,0 & 11,0 & 11,0 \\
Ekstrak 10\% & 13,0 & 14,0 & 13,5 & 13,5 \\
Ekstrak 20\% & 15,0 & 15,5 & 13,0 & 14,5 \\
Ekstrak 40\% & 16,0 & 15,0 & 14,0 & 15,0 \\
$\begin{array}{c}\text { Ciprofloxaci } \\
\text { n }\end{array}$ & 30,5 & 30,5 & 28,0 & 29,6 \\
\hline
\end{tabular}

Hasil pengujian daya hambat ekstrak polar rimpang kunyit (Curcuma longa) terhadap aktivitas pertumbuhan bakteri Pseudomonas sp memiliki nilai positif. Rata-rata diameter zona hambat pada ekstrak 5\%, 10\%, 20\% dan 40\% secara berurutan yaitu $8,8 \mathrm{~mm}, 9,3 \mathrm{~mm}, 11,1 \mathrm{~mm}$, dan $13,1 \mathrm{~mm}$. Hasil yang lebih jelas dapat diihat pada Tabel 2.

Tabel 2. Diameter zona hambat ekstrak rimpang kunyit terhadap bakteri Pseudomonas $s p$

\begin{tabular}{ccccc}
\hline Bahan Uji & $\begin{array}{c}\text { Petri } \\
\text { I } \\
(\mathrm{mm})\end{array}$ & $\begin{array}{c}\text { Petri } \\
\text { II } \\
(\mathrm{mm})\end{array}$ & $\begin{array}{c}\text { Petri } \\
\text { III } \\
(\mathrm{mm})\end{array}$ & $\begin{array}{c}\text { Rata- } \\
\text { rata } \\
(\mathrm{mm})\end{array}$ \\
\hline Aquades & 0,0 & 0,0 & 0,0 & 0,0 \\
Ekstrak 5\% & 8,0 & 9,0 & 9,5 & 8,8 \\
Ekstrak 10\% & 11,0 & 9,0 & 8,0 & 9,3 \\
Ekstrak 20\% & 13,0 & 10,0 & 10,5 & 11,1 \\
Ekstrak 40\% & 13,0 & 13,0 & 13,5 & 13,1 \\
Ciprofloxacin & 18,0 & 18,0 & 18,0 & 18,0 \\
\hline
\end{tabular}

\section{BAHASAN}

Pada penelitian ini dibuat ekstrak rimpang kunyit (Curcuma longa) dengan larutan etanol yang bersifat ekstraktor polar. ${ }^{8}$ Prinsip dasar penelitian adalah dengan pemberian bakteri Staphylococcus aureus dan Pseudomonas sp pada ekstrak rimpang kunyit (Curcuma longa) ke dalam sumur media agar diharapkan dapat terjadi penghambatan pertumbuhan bakteri. Penghambatan pertumbuhan tersebut dapat terlihat dengan adanya zona hambat pada media agar.

Metode ekstraksi yang digunakan adalah metode sumuran karena lebih cocok dan praktis untuk uji herbal atau obat yang berasal dari tanaman. Metode ini membuat ekstrak dapat berdifusi secara maksimal karena bahan akan bertemu langsung dengan media pertumbuhan sampai ke dasar media melalui sumur yang dibuat pada media pertumbuhan kuman. ${ }^{9}$

Penelitian menggunakan dua jenis bakteri yaitu gram positif Staphylococcus aureus dan gram negatif Pseudomonas sp dimana kedua bakteri tersebut adalah bakteri yang dapat menyebabkan infeksi pada manusia contohnya infeksi kulit dan pernapasan. ${ }^{10}$

Penggunaan beberapa konsentrasi ekstrak polar rimpang kunyit (Curcuma longa), yaitu 5\%, 10\%, 20\%, dan 40\% dimaksudkan agar dapat dibuktikan ada tidaknya efek farmakologi yang dimiliki ekstrak polar rimpang kunyit (Curcuma longa) berdasarkan konsentrasi yang berbeda.

Pada penelitian ini kontrol negatif yang digunakan adalah aquades sekaligus juga merupakan larutan pengencer kontrol positif maupun ekstrak rimpang kunyit (Curcuma longa). Ciprofloxacin dipilih sebagai kontrol positif yang merupakan larutan pembanding efek antara obat antimikroba baku dengan larutan ekstrak uji dalam hal ini rimpang kunyit (Curcuma longa). Pemilihan ciprofloxacin sebagai kontrol positif karena ciprofloxacin memiliki efek antimikroba yang luas dan resistensi mikroba tidak cepat berkembang. ${ }^{11}$

Pengamatan pada bakteri uji Staphylococcus aureus (lihat Tabel 1) terlihat bahwa aquades sebagai kontrol negatif tidak memiliki daya hambat. Ini ditunjukkan dengan tidak ditemukannya zona hambat disekitar sumur yang berisi aquades. Hal ini berbanding terbalik dengan larutan pembanding ciprofloxacin sebagai kontrol positif dimana terlihat 
memiliki zona hambat yang besar dan sangat menonjol dibandingan dengan empat larutan uji.

Larutan uji ekstrak rimpang kunyit (Curcuma longa) pada Tabel 1 dengan konsentrasi 5\% sudah menunjukkan adanya penghambatan terhadap pertumbuhan bakteri Staphylococcus aureus. Efek penghambatan makin kuat pada konsentrasi yang lebih besar yaitu pada konsentrasi $10 \%$, 20\%, dan 40\%. Hal tersebut membuktikan bahwa ekstrak rimpang kunyit (Curcuma longa) memiliki efek antimikroba terhadap bakteri Staphylococcus aureus.

Pengamatan uji bakteri sesuai Tabel 2, menunjukkan bahwa aquades sebagai kontrol negatif tidak menunjukkan efek antimikroba terhadap pertumbuhan bakteri Pseudomonas $s p$. yang ditunjukkan dengan tidak adanya zona hambat disekitar sumur yang berisi aquades. Larutan pembanding ciprofloxacin sebagai kontrol positif sebaliknya memiliki zona hambat terhadap bakteri Pseudomonas sp.

Larutan uji ekstrak rimpang kunyit (Curcuma longa) pada konsentrasi 5\% sudah menunjukkan efek antimikroba terhadap bakteri Pseudomonas sp. dan efek penghambatan makin kuat pada konsentrasi $10 \%$, 20\%, dan 40\%. Hal ini membuktikan bahwa ekstrak rimpang kunyit (Curcuma longa) memiliki efek antimikroba terhadap bakteri Pseudomonas sp.

Pada pengamatan ternyata efek antimikroba makin meningkat pada konsentrasi larutan uji berturut-turut dari 5\%, 10\%, 20\% dan 40\% baik pada bakteri Staphylococcus aureus maupun Pseudomonas sp. Hal ini menunjukkan adanya hubungan positif kuat antara konsentrasi dan zona hambat yang dihasilkan. Semakin tinggi konsentrasi maka semakin besar zona hambat yang terjadi. Artinya, larutan ekstrak polar rimpang kunyit (Curcuma longa) memiliki efek antimikroba terhadap bakteri Staphylococcus aureus dan Pseudomonas $s p$ dengan urutan kekuatan antimikroba pada larutan uji konsentrasi adalah 40\%, $20 \%, 10 \%, 5 \%$.
Berdasarkan hasil penelitian didapat bahwa ekstrak rimpang kunyit (Curcuma longa) memiliki kemampuan antimikroba terhadap bakteri Staphylococcus aureus dan Pseudomonas sp. Hal ini disebabkan adanya zat aktif yang terkandung dalam rimpang kunyit. Zat aktif yang terkandung dalam ekstrak rimpang kunyit (Curcuma longa) yang kemungkinan dapat menghambat pertumbuhan bakteri yaitu kurkuminoid (meliputi kurkumin, desmetoksikurkumin dan bisdesmetoksikurkumin) dimana dari ketiga senyawa tersebut, kurkumin merupakan komponen terbesar. ${ }^{12}$ Kurkumin berwarna kuning atau kuning jingga pada suasana asam, sedangkan dalam suasana basa berwarna merah. Zat ini tidak larut dalam air namun larut dalam etanol dan aseton. ${ }^{13}$ Kurkumin mempunyai efek antimikroba, antiinflamasi, anti-oksidan , dan antikanker. ${ }^{14}$

\section{SIMPULAN}

Berdasarkan hasil penelitian dapat disimpulkan bahwa ekstrak polar rimpang kunyit (Curcuma longa) mempunyai daya hambat terhadap pertumbuhan bakteri Staphylococcus aureus dan Pseudomonas $s p$ dengan urutan kekuatan penghambatan dari setiap konsentrasi yaitu $40 \%>20 \%>10 \%>5 \%$.

\section{SARAN}

Perlu dilakukan penelitian lebih lanjut efek antimikroba rimpang kunyit (Curcuma longa) terhadap bakteri yang lain,

Perlu dilakukan penelitian kandungan zat aktif rimpang kunyit (Curcuma longa) yang beraktivitas sebagai antibakteri serta mekanisme penghambatannya,

Perlu dilakukan uji aktivitas antimikroba lanjutan secara in vivo untuk menentukan dosis dan efek toksisitas, serta efek samping dari ekstrak polar rimpang kunyit (Curcuma longa)

\section{DAFTAR PUSTAKA}

1. Chaudhury RR. Herbal Medicine for Human Health. New Delhi: WHO Regional Publication; 2002. p. 1-30. 
2. Juckett G. Herbal Medicine. In: Craig CR, Stitzel RE, editors. Modern Pharmacology with Clinical Applications. $6^{\text {th }}$ ed. Philadelphia: Lippincott Williams \& Wilkins; 2004. p. 785.

3. Duggi S, Handral H, Tulsianand G, Shruthi SD. Turmeric: Nature's Precious Medicine. AJPCR. 2013;6:10-6.

4. Yadav D, Khar RK, Mujeeb M, Akhtar M. Turmeric (Curcuma longa L.): A Promising Spice for Phytochemical and Pharmacological Activities. IJGP. 2013;7:85-9.

5. Dalimartha S. Atlas Tumbuhan Obat Indonesia. Edisi ke-6. Jakarta: Pustaka Bunda; 2009. h. 76-82.

6. Hidayati E, Juli N, Marwani E. Isolasi Enterobacteriaceae Patogen Dari Makanan Berbumbu dan Tidak Berbumbu Kunyit (Curcuma longa L.) Serta Uji Pengaruh Ekstrak Kunyit (Curcuma longa L.) Terhadap Pertumbuhan Bakteri yang Diisolasi. Bandung: Departemen Biologi; 2002.

7. Antunes SA, Rolazza WS, Schittler L, Gomes GA. Synergistic and Antimicrobial Properties of Commercial Turmeric (Curcuma longa L.) Essential Oil Against
Pathogenic Bacteria. FST. 2012;32:711.

8. Posangi J. Buku Penuntun Praktikum: Ekstraksi. Manado: Bagian Farmakologi dan Terapi Fakultas Kedokteran Unsrat; 2000. h. 3-4.

9. Gould D, Brooker C. Mikrobiologi Terapan Untuk Perawat. Jakarta: EGC; 2005. h. 69-73.

10. Elliot T, Worthington T, Osman $H$, Gill M. Mikrobiologi Kedokteran dan Infeksi. Edisi ke-4. Jakarta: EGC; 2013. h. 23-6,61-2.

11. Chana A, Ashfaq M, Mastoi SM. Effect of Ciprofloxacin On Growing Cartilage in Albino Rat Pups. J Ayub Med Coll Abbottabad. 2006;18:50.

12. Cahyono B, Huda MDK, Limantara L. Pengaruh Proses Pengeringan Rimpang Temulawak Terhadap Kandungan dan Komposisi Kurkuminoid. Reaktor. 2011;13:166.

13. FAO. Curcumin Chemical and Technical Assessment. 2004 [cited 2016 Jan 12]. Available from: ftp://193.43.36.93/es/esn/jecfa/cta/CT A_61_Curcumin.pdf

14. Kwon Y, Magnuson BA. Age-related Differential Responses to CurcuminInduced Apoptosis During The Initiation of Colon Cancer In Rats. Food Chem Toxicol 2009;47:377-85. 